\title{
Early stages of the natriuretic hormone story
}

\author{
Branislav Lichardus ${ }^{1,2 *}$ \\ 1 School of Management, City University of Seattle Programs, Bratislava, Slovakia \\ ${ }^{2}$ Formerly affiliated with The Institute of Experimental Endocrinology, Slovak Academy of Sciences, Bratislava, Slovakia
}

\section{Edited by:}

Harvey Craig Gonick, University of California Berkeley, USA

\section{Reviewed by:}

Vardaman Buckalew, Wake Forest

School of Medicine, USA

Mordecai P. Blaustein, University of

Maryland School of Medicine, USA

*Correspondence:

Branislav Lichardus, School of

Management, Panónska cesta 17,

Bratislava 851 04, Slovakia

e-mail: blichardus@vsm.sk
The paper reviews the early stages of the research on natriuretic hormone. The described experimental work was designed and accomplished in several internationally recognized laboratories where the author was invited to extend his projects. The cross-circulation experiments in animals with acutely increased extracellular fluid volume documented, that in the mechanism of natriuresis - besides a series of the physical natriuretic factors there is still room for an active humoral natriuretic substance. This substance inhibited the sodium transporting enzyme, Na, K-ATPase, in the frog skin. Analogous inhibition of the renal $\mathrm{Na}, \mathrm{K}-\mathrm{ATPase}$ may be partly responsible for the increased sodium excretion. It was further shown that the extent of natriuresis is positively modulated by the concentration of sodium in the cerebrospinal fluid detected in the anterior-third ventricle region (AV3V) in the brain.

Keywords: natriuretic hormone, cross-circulation experiments, Na,K-ATPase, anterior-third ventricle region-AV3V, cerebrospinal fluid sodium concentration
The first International "Symposium on Natriuretic Hormone" was held at the Smolenice Castle, the Congress Center of the Slovak Academy of Sciences in 1969, 12 years after the suggestion of Homer Smith that some such factor could exist (1) and 8 years since the first corroborative experimental data were presented by the team of Hugh de Wardener (2). At the next symposium organized by the same Institution, a decade later we dealt rather with "Natriuretic Hormones" (3). This review is a selected account on the elaboration of the early stages of the hypothesis on the existence of a natriuretic hormone in which I was privileged to participate.

\section{CROSS-CIRCULATION EXPERIMENTS AND "rein au cou"}

In the experiments of de Wardener et al. (2), evidence was advanced for the transfer of a natriuretic material from the donor dog with expanded extracellular fluid volume (ECFV) by the infusion of saline to the cross-perfused recipient dog. The experiments were arranged in such a way that the provoked natriuresis and urine excretion in the recipient animal was neither a result of an increase of the glomerular filtration rate nor of the decrease of known circulating hormones, anti-natriuretic steroids, and vasopressin. Consequently, a third factor was suggested to be involved.

Our group, in pursuing this provocative idea, modified the cross-perfusion experiment in dogs. Only one kidney in situ in the recipient dog was cross-perfused under constant perfusion pressure by the donor's blood in order to expose the recipient kidney to a larger concentration of a natriuretic material than in cross-perfusion of the whole animals. To prevent a possible natriuretic effect of blood dilution by saline infusion rather the blood volume of the donor dog was expanded by an "artificial blood" (suspension of homologous erythrocytes in 6\% bovine albumin in Ringer-Locke solution). The cross-perfused kidney increased sodium and urine excretion following the blood volume expansion of the donor dog. However, this "transferred natriuresis" was less pronounced than natriuresis provoked by infusion of saline in the previous experiment of de Wardener. It was concluded that even if the natriuretic effect of blood dilution is eliminated the cross-perfusion experiments may reveal the appearance of a natriuretic factor in blood of the donor dog following its blood volume expansion (4). It was established in other experiments that the bovine albumin in the "artificial blood" as such was not critical for natriuresis evoked by blood volume expansion (5).

Yet, in another experimental set up, the homologous kidney was transplanted to the neck of a dog ("rein au cou") in which vasopressin and creatinine were infused and DOCA was administered intramuscularly at least $3 \mathrm{~h}$ before the urine collection started. Subsequently, the blood volume of the dog with the transplanted kidney was expanded by infusion of homologous blood. The experimental conditions assured constant renal arterial and venous pressures in the transplanted kidney, a constant plasma oncotic pressure and constant hematocrit, glomerular filtration rate, and renal blood flow. Moderate, when compared with the renal output of the other kidney in situ, but significant increase in urine output and sodium excretion was observed by the transplanted kidney. Since non-hormonal and hormonal factors modulating sodium and water excretion were kept under control in the transplanted kidney, the results indicated more specifically than in previous experiments that a natriuretic humoral material might play a role in the mechanism of natriuresis provoked by blood volume expansion (6).

The operation of a blood-borne natriuretic factor in rat crosscirculation experiment was shown only when so-called sustained fluid volume expansion was achieved by urine reinfusion in the expanded donor animal. This procedure apparently intensified the natriuretic signal to the recipient animal (7).

\section{A NATRIURETIC OR A DILUTION OF AN ANTI-NATRIURETIC SUBSTANCE?}

Our next attempt was to challenge the question that emerged from the cross-circulation experiments, namely, whether the 
appearance of a putative blood-borne natriuretic factor in animals with expanded ECFV was the result of an increased concentration of a natriuretic or a dilution of an anti-natriuretic substance. The experiments were performed on un-anesthetized cows, from which substantial volume of blood can be removed without reversing the effect induced by the expansion of their ECFV with $6 \%$ dextran in physiological saline $(30 \mathrm{ml} / \mathrm{kg}$ b.w. at a rate of $100 \mathrm{ml} / \mathrm{min}$ ). A blood sample of $1000 \mathrm{ml}$ was withdrawn before the infusion and another one at the end of the infusion. The deproteinized plasma was applied intravenously to the assay rats in a volume of $0.2 \mathrm{ml}$. A non-significant tendency of control samples rather to decrease both the rate of urine flow and sodium excretion in the assay animals, was observed. On the other hand, the samples withdrawn during the ECFV expansion in cows produced statistically significant increases in urine flow, sodium excretion, and the tubular fractional sodium excretion in the assay rats. The sensitivity of the biological assay (i.e., the natriuretic activity applied in $0.2 \mathrm{ml}$ of deproteinized plasma) might indicate that a separate low-molecular weight natriuretic factor might be involved, and that we are not dealing with a mere dilution effect of infusion on an anti-natriuretic activity (8).

The same plasma sample also decreased the short-circuit current representing active sodium transport in the frog skin by a transporting enzyme Na,K-ATPase $(9,10)$. Buckalew et al. (11) showed that an ultrafiltrate of blood from volume expanded dogs inhibited sodium transport in the toad bladder. It may be another indication for the presence of a natriuretic material in the tested plasma sample as it was proposed that the renal mechanism of natriuresis is via inhibition of the transporting enzyme in the nephron (12).

Further elaboration of the concept of an endogenous inhibitor of the Na,K-ATPase resulted in an attractive hypothesis linking the inhibitor to digoxin-like activity found in some organs, blood, and urine and to the pathogenesis of essential and low-renin arterial hypertension (13-16). Indeed, it was subsequently found that anti-digoxin serum decreased blood pressure in young rats with DOCA-salt hypertension (17). The same anti-digoxin serum, however, was ineffective in suppressing natriuresis induced by ECFV expansion with saline in rats (18). This finding illustrated at that time that the number and nature of substances represented by the endogenous digoxin-like activity had not been satisfactorily answered (19-21), which is true even now.

\section{INVOLVEMENT OF PERIPHERAL AND CENTRAL NERVOUS SYSTEM IN THE SODIUM BALANCE}

The reflex regulation of renal water excretion originating in the stretch receptors of heart atria having the vagal nerves as the afferent limb and vasopressin as an efferent limb (Gauer-Henry reflex) was proposed to be applicable also to the mechanism of renal regulation of sodium excretion. The efferent limb of the reflex was presumed to be a natriuretic factor produced in the brain. However, we found that natriuresis induced by infusion of artificial blood in dogs with either innervated or denervated kidneys was not abolished by bilateral vagotomy. Thus, the analogy of reflex renal sodium control with a modified Gauer-Henry reflex did not seem to be primarily at play (22). We, unfortunately, did not offer at that time a more creative conclusion from these experiments.
It is obvious today that -14 years before the discovery of atrial natriuretic peptides - we missed a possibility to speculate about the role of the heart as such in the renal sodium excretion during the ECFV expansion. Our shortcoming in judgment was partly due to the fact that others found the afferent signal to travel along afferent sympathetic nerves and the spinal cord which, of course, were not interrupted by vagotomy.

It has been shown in various species of anesthetized or conscious experimental animals that increased concentration or dilution of sodium salts in the cerebrospinal fluid (CSF) interfere, respectively, with renal sodium excretion (23). In our studies on conscious sheep, the increase in the CSF sodium concentration and the simultaneous expansion of the ECFV resulted in a much higher increase in renal sodium excretion in comparison to the effect of ECFV expansion in animals with normal CSF sodium concentration. Dilution of CSF sodium prevented completely natriuresis following the ECFV expansion. This is thus another indication of that the brain may be involved in the control of renal regulation of ECFV by monitoring sodium concentration in CSF (24).

The periventricular organs that lack the blood-brain barrier seem to be critical for changes in CSF and also in the systemic ECF sodium concentration. A critical brain area where the sodium concentration or osmolality is monitored is probably the anterior wall of the third ventricle (AV3V). This conclusion is supported by experiments in conscious sheep with ablated AV3V. The nonlesioned control sheep were in a spontaneous water balance, whereas water balance in the animals with chronically ablated $\mathrm{AV} 3 \mathrm{~V}$ region was re-established by forced application of drinking water through intrarumenal tube. It was found that ablation of $\mathrm{AV} 3 \mathrm{~V}$ region blocks natriuresis to hypertonic but not isotonic $\mathrm{NaCl}$ load provided the lesioned sheep is in water balance. McKinley et al. $(25,26)$ suggested that the AV3V region has a role in regulation of renal $\mathrm{Na}$ excretion in conditions where the plasma $\mathrm{Na}$ concentration increases. It was further proposed that increased renal $\mathrm{Na}$ excretion in response to hypernatremia is another cerebrally mediated osmoregulatory response. However, the AV3V region does not seem to be critical for the mechanism of natriuresis induced by ECFV expansion with isotonic saline $(24,26,27)$.

The posterior hypothalamus was also found to be involved in the sodium and ECFV balance. Lesions in the posterior nucleus of the hypothalamus are followed by a renal salt wasting syndrome in rats, cats, and man. In both animal experiments and clinical cases, it was shown that this type of negative sodium balance could not be corrected by adrenal steroids. We tried to identify in rats whether the nuclei in the posterior hypothalamus react to the disturbed sodium balance. The rats were given only a $2 \%$ saline to drink for 10 days. A control group drank tap water. The hypothalami were then sectioned and the volume of 200 cell nuclei was determined in each animal of the following nuclei: posterior, ventromedialis, dorsomedialis, and arcuate. The distribution of cell nuclear volume size showed a statistically significant decrease only in the posterior hypothalamic nucleus, which might suggest that it could have been specifically influenced by increased sodium concentration in blood and/or in CSF. At the time of this experiment, changes of volume of cell nuclei in the nucleus posterior hypothalami were taken for an indication of their neuroendocrine activity in connection with salt loading $(28,29)$. 


\section{CONCLUSION}

Using modified cross-perfusion experiments, in which the blood was not diluted, a methodology was put forward to exclude the natriuretic effect of physical factors. It was confirmed that during blood volume expansion a natriuretic or dilution of anti-natriuretic material was revealed.

It was shown, in an attempt to isolate the presumed substance playing a role in natriuresis following the blood or the whole ECF volume expansion that it may be a substance with a natriuretic activity.

The isolated substance also decreased the short-circuit current in the frog skin, which is an indication for its potential to decrease the activity of the transporting enzyme $\mathrm{Na}, \mathrm{K}-\mathrm{ATPase}$. This action of the natriuretic substance could be its contribution to the renal mechanism of natriuresis following ECFV expansion.

It was shown in conscious sheep that the brain is involved in the control of renal regulation of ECFV by monitoring sodium concentration in CSF. A critical brain area, as indicated by others, where the sodium concentration or osmolality is monitored is the anterior wall of the third ventricle (AV3V).

Indirect evidence was presented for a neuroendocrine activity of the nucleus posterior hypothalami related to the sodium balance in rats.

\section{REFERENCES}

1. Cort JH, Lichardus B. Introductory remarks. In: Cort JH, Lichardus B, editors. Regulation of Body Fluid Volumes by the Kidney-Symposium on Natriuretic Hormone. Basel: S. Karger (1970). p. 1-10.

2. de Wardener HE, Mills IH, Clapham WF, Hayter CJ. Studies on efferent mechanism of sodium diuresis which follows administration of intravenous saline. Clin Sci (1961) 21:249-58.

3. Lichardus B. Natriuretic hormones. In: Lichardus B, Schrier RW, Ponec J, editors. Hormonal Regulation of Sodium Excretion. Amsterdam: Elsevier/North Holland Biomedical Press (1980). p. 1-7.

4. Lichardus B, Pearce JW. Evidence for a humoral natriuretic factor released by blood volume expansion. Nature (1966) 209:407-9. doi:10.1038/209407a0

5. Sonnenberg H, Pearce JW. Renal response to measured blood volume expansion in differently hydrated dogs. Am J Physiol (1962) 203:344-52.

6. Lichardus B, Nizet A. Water and sodium excretion after blood volume expansion under condition of constant arterial, venous and plasma oncotic pressures and constant haematocrit. Clin Sci (1972) 42:701-9.

7. Pearce JW, Sonnenberg H, Lichardus B, Veress AT. Interaction of extrarenal and intrarenal factors in volume natriuresis. In: Cort JH, Lichardus B, editors. Regulation of Body Fluid Volumes by the Kidney - Symposium on Natriuretic Hormone. Basel: S. Karger (1970). p. 72-92.

8. Lichardus B, Pliska V, Uhrin V, Barth T. The cow as a model for investigating natriuretic activity. Lancet (1968) 291:127-9. doi:10.1016/S0140-6736(68) 92728-1

9. Sedlakova E, Lichardus B, Cort JH. Plasma saluretic activity: its nature and relation to oxytocin analogs. Science (1969) 64:580-2. doi:10.1126/science.164. 3879.580

10. Lichardus B, Pliska V, Uhrin V, Barth T. Natriuretic and antinatriferic activities in deproteinised bovine plasma after dextran infusion. In: Cort JH, Lichardus B, editors. Regulation of Body Fluid Volumes by the Kidney-Symposium on Natriuretic Hormone. Basel: S. Karger (1970). p. 114-21.

11. Buckalew VM Jr, Martinez FJ, Green WJ. The effect of dialysates and ultrafiltrates of plasma of saline-loaded dogs on toad bladder sodium transport. J Clin Invest (1970) 49:926-35. doi:10.1172/JCI106312

12. Kramer HJ, Gonick HC. Effect of extracellular volume expansion on renal $\mathrm{Na}, \mathrm{K}-$ ATPase and cell metabolism. Nephron (1974) 12:281-96. doi:10.1159/000180341
13. Haddy F, Overbeck $H$. The role of humoral agents in volume expanded hypertension. Life Sci (1976) 19:935-47. doi:10.1016/0024-3205(76)90284-8

14. Blaustein MP. Sodium ions, calcium ions, blood-pressure regulation and hypertension - reassessment and hypothesis. Am J Physiol (1977) 232:C165-73.

15. Gruber KA, Buckalew VM Jr. Evidence that natriuretic factor is a cascading peptide hormone system. In: Lichardus B, Schrier RW, Ponec J, editors. Hormonal Regulation of Sodium Excretion. Amsterdam: Elsevier/North Holland Biomedical Press (1980). p. 342-8.

16. de Wardener HE, MacGregor G. The natriuretic hormone and essential hypertension. In: Lichardus B, Schrier RW, Ponec J, editors. Hormonal Regulation of Sodium Excretion. Amsterdam: Elsevier/North Holland Biomedical Press (1980). p. 387-90.

17. Zicha J, Kunes J, Stolba P. Endogenous digoxin-like factor contributes to the elevation of systemic resistance in rats exposed to high-salt intake from prepuberty. J Hypertens Suppl (1985) 3:S17-9.

18. Lichardus B, Zicha J, Ponec J, Stolba P, Pohlova I. Anti-digoxin serum with antipressoric properties is ineffective in attenuating natriuresis during extracellular fluid volume expansion. Physiol Bohemoslov (1986) 35:361.

19. Lichardus B. Natriuretic hormones in volume natriuresis. Physiol Res (1991) 40:161-8.

20. Lichardus B, Kovacs L. Natriuretic hormone as a circulating inhibitor of $\mathrm{Na}, \mathrm{K}-$ ATPase. In: Bittar E, Bittar N, editors. Molecular and Cellular Endocrinology. London: JAI Press Inc (1997). p. 501-15.

21. Buckalew VM. Endogenous digitalis-like factors. An historical overview. Front Biosci (2005) 10:2325-34. doi:10.2741/1701

22. Pearce JW, Lichardus B. Effects of vagotomy and renal denervation on renal response to blood volume expansion. J Physiol Pharmacol (1967) 45:689-703. doi:10.1139/y67-082

23. McKinley MJ, Congiu M, Denton DA, Lichardus B, Park E, Tarjan E, et al. Cerebrospinal fluid composition and homeostatic responses to dehydration. In: Schrier RW, editor. Vasopressin. New York, NY: Raven Press (1985). p. 299-309.

24. Lichardus B, Ponec J, McKinley MJ, Okolicany J, Gabauer I, Styk J, et al. The anterior third ventricle region is a receptor site for composition rather than volume of body fluids. In: Porter C, Jezova D, editors. Circulating Regulatory Factors and Neuroendocrine Function. New York, NY: Plenum Press (1990). p. 211-26.

25. McKinley MJ, Congiu M, Denton DA, Park RG, Penschow J, Simpson JB, et al. The anterior wall of the third cerebral ventricle and homeostatic responses to dehydration. J Physiol (Paris) (1984) 79:421-7.

26. McKinley MJ, Lichardus B, McDougal JG, Weisinger RS. Periventricular lesions block natriuresis to hypertonic but not isotonic $\mathrm{NaCl}$ loads. Am J Physiol (1992) 262:F98-107.

27. Lichardus B, McKinley MJ, Denton DA, Ponec J. Brain involvement in the regulation of renal sodium excretion. Klin Wochenschr (1987) 65:33-9.

28. Lichardus B, Mitro A, Cort JH. Size of cell nuclei in the hypothalamus of the rat as a function of salt loading. Am J Physiol (1965) 208:1075-7.

29. Bajuzs E. Modern trends in neuroendocrinology with special reference to clinical problems. A concluding review. In: Bajuzs E, editor. An Introduction to Clinical Neuroendocrinology. New York, NY: S. Karger (1967). p. 428-534.

Conflict of Interest Statement: The author declares that the research was conducted in the absence of any commercial or financial relationships that could be construed as a potential conflict of interest.

Received: 26 August 2014; paper pending published: 19 September 2014; accepted: 07 October 2014; published online: 11 November 2014.

Citation: Lichardus B (2014) Early stages of the natriuretic hormone story. Front. Endocrinol. 5:180. doi: 10.3389/fendo.2014.00180

This article was submitted to Neuroendocrine Science, a section of the journal Frontiers in Endocrinology.

Copyright $(9) 2014$ Lichardus. This is an open-access article distributed under the terms of the Creative Commons Attribution License (CC BY). The use, distribution or reproduction in other forums is permitted, provided the original author(s) or licensor are credited and that the original publication in this journal is cited, in accordance with accepted academic practice. No use, distribution or reproduction is permitted which does not comply with these terms. 